\title{
THE GENETIC POTENCY OF PLANTAIN AGUNG SEMERU VARIETY FROM LUMAJANG REGENCY EAST JAVA INDONESIA
}

\author{
P.E.R. Prahardini , Yuniarti and Amik Krismawati
}

Assessment Institute for Agricultural Technology East Java, Indonesia

\begin{abstract}
Lumajang regency is one of the banana production centre in East Java having high-diversity of banana germ plasm. There are 33 cultivars of banana germ plasm in the regency, consist of eaten ripe and plantain. One of uniqe plantain used as the symbol of Lumajang regency is plantain Agung Semeru variety, the local superior variety of this regency. This variety can grow well at $450-650 \mathrm{~m}$ above sea level. The uniqueness of banana Agung Semeru variety can be seen by the number of sucker per cluster (only 1-2 suckers per cluster), the size of the finger (33-36 cm long and $19 \mathrm{~cm}$ around) and the number of hand per bunch (only $1-2$ hand per bunch). Other characteristics of the variety are the thickness of fruit skin, the long period of fruit storage (3-4 weeks after harvesting) and the sweetness of fruit flesh. Even though the skin changes from yellow to black, the flesh still can be consumed, because it doesn't become soft. This variety also resistant to the Sigatoka disease compared to other plantain cultivars.
\end{abstract}

Key words: Banana germ plasm, superior variety, plantain Agung Semeru variety

\section{Introduction}

Banana especially plantain is already well known as tropical fruit and highly potencial to be developed in similar agroecological zone in East Java. Besides that, its taste, its nutrient content, vitamin and calory is also very useful to keep the body healthy.

Based on the growth requirements, plantain grow well from low land till the altitude of $1000 \mathrm{~m}$ above sea level, $\mathrm{pH} 4,5-7,5$. Plantain has shallow roots, spread out under the soil and needs soil containing much organic matters.

Plantain var. Agung Semeru is one of new released variety. For this time being, it is become a trade mark of Lumajang, and widely consumed as processed product, such as chips, sale and powder. The main producer area in Lumajang is at Senduro district.

\section{Genetic Resources}

Plantain var. Agung Semeru found at Senduro district Lumajang, its originally growing in this location, spread out at 12 villages. Besides that, there are 33 cultivars of banana germ plasm in those regency, consist of eaten ripe (Emas, Ambon, Susu variety, ect) and plantain (Kepok, Byar, and Embug variety ect.). Based on the information provided by Extension Office for Agriculture, this varieties was already exist since long time ago.
Propagation of this varieties is ussually done vegetatively by using sucker or bulb. Based on the genetic characteristics (morphology, growth characters and production) of two kinds of plantain grown at two districts, namely Senduro and Pasru Jambe and supported by isozym analysis, the two of them belong to one varieties, var. Agung Semeru.

\section{Field test and Observation} Material and Method

Field test and observation was done in 2003 - 2006, at two districts namely Senduro and Pasru Jambe, using an interview method and observation. Interview using a questionaire actively involved farmers, extensionists and researchers.

Observation was done on $10-24$ monthold- plantain, by identifying and characterizing in the field and laboratory. Pests and diseases observation was done using a survey method on the existing plantation at the two locations.

\section{Result and Discussion}

The average of plantation grown at Senduro and Pasru Jambe was presented in Table 1, while farmer's profile in Table 2 and average pests and diseases attack in Table 3 .

Table 1. The average and production of plantain var. Agung Semeru at Senduroand Pasru Jambe, lumajang

\begin{tabular}{lccc}
\hline \multicolumn{1}{c}{ The name of district } & Wide (Ha) & $\begin{array}{c}\text { Populatin } \\
\text { (number of plants) }\end{array}$ & $\begin{array}{c}\text { Number of } \\
\text { farmers }\end{array}$ \\
\hline Senduro & 323,0 & 209.950 & 8.398 \\
Pasru Jambe & 217,7 & 261.240 & 528 \\
\hline
\end{tabular}

Agrict. Dept. of Lumajang regency, 2005 
Table 2. Farmer' profile of plantain var. Agung Semeru in Lumajang regency

\begin{tabular}{|c|c|c|c|c|}
\hline $\begin{array}{l}\text { The name of } \\
\text { farmers }\end{array}$ & Location & $\begin{array}{c}\text { Number of } \\
\text { plants (stem) }\end{array}$ & $\begin{array}{l}\text { Age of plant } \\
\text { month }\end{array}$ & Elevation \\
\hline Nanang Khosim & $\begin{array}{l}\text { Kandangan village, } \\
\text { Senduro }\end{array}$ & 150 & $10-15$ & $\begin{array}{c}650 \mathrm{~m} \text { above sea } \\
\text { level }\end{array}$ \\
\hline Sugiyo & $\begin{array}{l}\text { Kandang Tepus village, } \\
\text { Senduro }\end{array}$ & 30 & $18-24$ & $\begin{array}{c}600 \mathrm{~m} \text { above sea } \\
\text { level }\end{array}$ \\
\hline Sucipto & $\begin{array}{l}\text { JambeArum-village, Pasru } \\
\text { Jambe }\end{array}$ & 1500 & $12-15$ & $\begin{array}{c}450 \mathrm{~m} \text { above sea } \\
\text { level }\end{array}$ \\
\hline
\end{tabular}

Agrict. Dept. of Lumajang regency, 2003

Table 3. Average pests and diseases on attack, intensity and population of plantain var. Agung Semeru at Senduro- Lumajang regency

\begin{tabular}{lcccc}
\hline \multicolumn{1}{c}{ pests and diseases } & Attact (\%) & Intensity (\%) & Population & \\
\hline Erionata thrax & 57 & 34,57 & 22,43 & Moderat \\
\hline $\begin{array}{c}\text { Nacolea } \text { octosema } \\
\text { (scab moth), }\end{array}$ & 15 & 4,13 & - & Resistant \\
\hline Sigatoka disease & 26,67 & 4 & - & Resistant \\
\hline
\end{tabular}

Outstanding characteristics of plantain var. Agung Semeru

Based on:

1. It's usefulness, it can be consumed as processed food, raw material in home industry, such as fried banana, chips, sale, dodol, jams, wine, dried chips and powder.

2. It's unique performance, with big size compared to other varieties of plantain

3. Resistency towards pests and diseases: very resistent towards $N$. octosema, $E$ thrax, and fusarium

4. Yield: flowering $8-10$ months after planting with $10-20 \mathrm{~kg} /$ bunch of production

5. Having $1-2$ suckers/ cluster, so that it will be efficiently managed

6. Having relatively thick and hard fruit skin, so that self life will be longer and its' taste become sweeter

\section{Weaknesses}

Weaknesses caused by genetic factor, plant regeneration after three-years of growing, as younger sucker grown on old-roots, so it should be removed and replanting in other location.

Limited number of suckers resulted limited production of suckers to be grown (multiplied), so it needs rapid propagation through bit production and tissue culture

\section{Consumers' preference}

This plantain is widely consumed for household or home industry, for its'colour of fruit flesh (reddish yellow), compact structure and fresh and sour taste that make it difference with other varieties. Based on the size of finger $( \pm 19 \mathrm{~cm}$ of diameter, $33-36 \mathrm{~cm}$ of fruit length) and life storage $( \pm 3-4$ weeks after harvest), it is really prefered as processed food. Even its'fruitskin become black, it is still consumeable, its'fruit flesh is not soft. In mature condition, its' chip colour is yellow so consumer prefered to this

\section{Suitable Region}

The altitude of Senduro district, where this plantain grown was $475-600 \mathrm{~m}$ above sea level, dominated by oxisol soil type, with rainy season September - May, while day season is June till August (Oldeman), with less than three months of dry months, it showed moist condition (Saraswati et al, 2001). Average yearly rainfall (for 10 years) $2825.8 \mathrm{~mm}$ with 138 days of rainy.

To meet the demand of plantain var. Agung Semeru, that tended to be increased more and more, extensification should anticipated to provide raw material for home industry by considering the growth requirements as stated in Table 4, similar agroecological condition. 
Table 4. Growth requirements for planting var. Agung Semeru grown at Sendduro district, Lumajang

\begin{tabular}{ll}
\hline \multicolumn{1}{c}{ Characteristics of growth requirement } & Unit \\
\hline Annual average temperature $\left({ }^{\circ} \mathrm{C}\right)$ & $22^{\circ}-28^{\circ} \mathrm{C}$ \\
\hline Altitude & $475-600 \mathrm{~m}$ above sea level \\
\hline Yearly rainfall & $2825,8 \mathrm{~mm}$ \\
\hline Day season $(<100 \mathrm{~mm})$ & $<3$ bulan \\
\hline Tecsture $*$ & Clay \\
\hline C/N ratio* & 7 \\
\hline Soil pH & 6 \\
\hline Drainage & good \\
\hline Sloping rate & $<18 \%$ \\
\hline
\end{tabular}

\section{Description}

\section{Observation component}

\section{Result}

\begin{tabular}{|c|c|}
\hline Origin & Kandangtepus village, Senduro, Lumajang \\
\hline Age of plant & 18 month \\
\hline Age of flowering & $8-10$ month after planting \\
\hline Age of harvesting & $12-14$ month after planting \\
\hline Stem & Erect \\
\hline Plant height & $6-8 \mathrm{~m}$ \\
\hline Colour of stem & Reddish - green \\
\hline Colour of base - stem & Brownish - red \\
\hline Diameter of stem & $60-80 \mathrm{~cm}$ \\
\hline Width of canopy & $3-4 \mathrm{~m}$ \\
\hline Number of leaves & $8-11$ helai \\
\hline Length of leaf & $1,5 \mathrm{~m}$ \\
\hline Width of leaf & $60-70 \mathrm{~cm}$ \\
\hline Angle of leaf & $30^{\circ}$ \\
\hline Shape of leaf & Flat - long \\
\hline Leaves colour & $\begin{array}{l}\text { Shiny-dark-green above, light-green under, main } \\
\text { leaf-stem having red colour }\end{array}$ \\
\hline Edge of leaf & Acuminate \\
\hline Leaf border & Smooth, waving and having purplesh - red \\
\hline Leaf structure & One on another \\
\hline Flower & Oval \\
\hline Flower sheat colour & $\begin{array}{l}\text { Outside: Brownish - red } \\
\text { Inside: Light - pink }\end{array}$ \\
\hline Length of flower & $70 \mathrm{~cm}$ \\
\hline Diameter of flower & $30 \mathrm{~cm}$ \\
\hline Length of flower stalk & $69,5 \mathrm{~cm}$ \\
\hline Number of sucker/ cluster & $1-2$ \\
\hline Number of hand/ bunch & $1-2$ \\
\hline Number of finger/ hand & $1,3,10-18$ \\
\hline Fruit weight per bunch & $10-15 \mathrm{~kg}$ \\
\hline Observation component & Result \\
\hline Bunch diameter & $122 \mathrm{~cm}$ \\
\hline Length of stalk'bunch & $58 \mathrm{~cm}$ \\
\hline Diameter of stalk'bunch & $18 \mathrm{~cm}$ \\
\hline
\end{tabular}


P.E.R. Prahardini, Yuniarti and Amik Krismawati

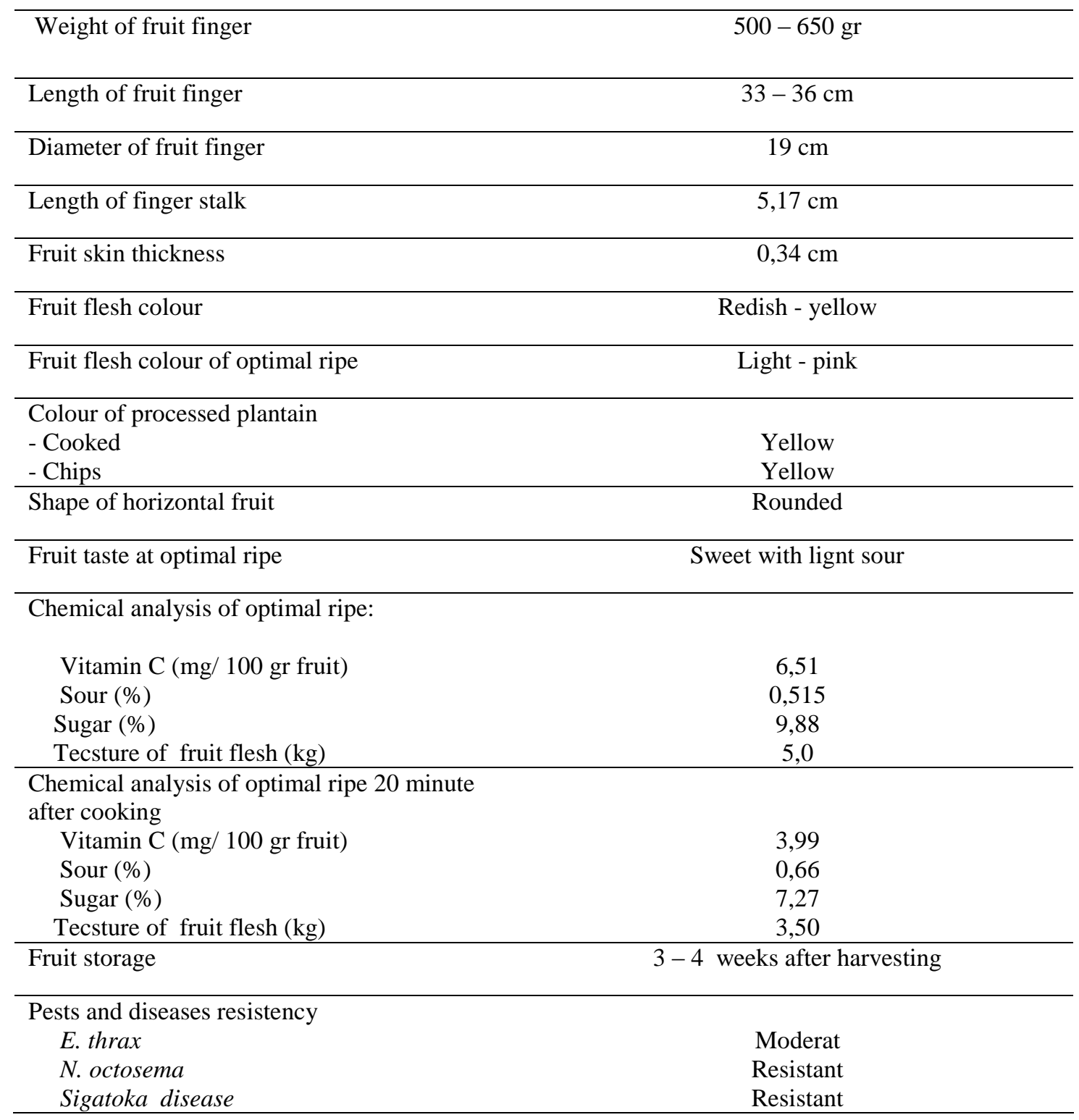

\section{Conclusion}

$>$ This plantain grow well at $475-600 \mathrm{~m}$ above sea level

$>$ The consumers' preference: Banana plantain of Agung Semeru variety can be used for: banana chip, banana cooking, banana flour, and others.

Besides that the fruit have long life storage

* Agung Semeru variety resistant to the Sigatoka disease compared to the other plantain cultivars

\section{References}

Allard, R.W. 1989. Pemuliaan Tanaman 2. Bina Aksara. Jakarta. Hal. 339 - 409.

BPTP Sumut. 1997. Petunjuk teknis budidaya pisang barangan. $30 \mathrm{~h}$.

Cabang Dinas Pertanian Senduro. 2002. Laporan perkembangan areal dan populasi tanaman pisang di Kecamatan Senduro.
Direktorat Bina Perlindungan Tanaman. 1997. Penyebaran penyakit penting pada tanaman hortikultura prioritas (buahbuahan). $86 \mathrm{~h}$.

Ernawanto, Q.D., D.D. Wijayanto, E. Sugiartini dan F. Kasijadi. 1997. Pengkajian Paket Teknik Budidaya Pisang di Lahan Kering. Laporan Hasil Penelitian TA 1996/1997. BPTP Karangploso Malang.

Handoko, L. Rosmahani, M.C. Mahfud, C. Hermanto dan N.I. Sidik. 1996. Aplikasi Penegendalian Hama dan Penyakit Penting Pada Tanaman Pisang di Lahan Kering. Laporan Hasil Penelitian TA 1995/ 1996. BPTP Karangploso Malang.

Horber E. 1979. Types and classification of resistance. Eds: Maxwell FG and Jennings PR. Breeding plants resistant to insects. 684 p.

Kasijadi, F. 2001. Prospek Pengembangan Pisang agung di Kabupaten Lumajang. Makalah 
disampaikan pada Temu Teknis Penyuluh Pertanian Kabupaten Lumajang. 13 hal.

Kogan M, Ortman EE. 1978. Antixenosis a new term porposed to replace Painters "Nonpreference" modality of resistance. ESA Bull 24.

Kusumo, S; R.E. Nasution; H. Sunarjono. F.A. Bahar dan S. Pratikno. 1996. Koleksi, Konservasi dan Evaluasi Plasma Nutfah Pisang. Laporan Hasil Penelitian RUT I. Proyek Pusat Penelitian Ilmu Pengetahuan Dan Teknologi Serpong. 40 hal.

Prahardini, P.E.R. 2003. Teknologi Pembibitan Pisang secara Konvensional dan Kultur Jaringan. Makalah disampaikan pada Temu Aplikasi Teknologi antara Peneliti, Penyuluh, Petani, Dinas Pertanian dan Dinas Terkait di Kabupaten Trenggalek tanggal 21 Juli 2003. 13 hal.

Saraswati, D.P., Suyamto, H., D. Setyorini, Al. G. Pratomo dan L.Y. Krisnadi. 2001. Zona Agroekologi Jawa Timur. Buku 1 Zonasi dan Karakterisasi Sumberdaya Lahan. BPTP Jawa Timur. 28 hal.

Sumarno. 2003. Potensi dan Peluang Usaha Agribisnis Buah Tropika dalam Era Pasar Bebas. Seminar Nasional "Daya Saing Sektor Pertanian Memasuki AFTA 2003" BPTP Jawa Timur. Malang. 14 hal. 